\title{
DRUŠTVENA REPREZENTACIJA NOVIH PSIHOAKTIVNIIH SUPSTANCI NA HRVATSKIM PORTALIMA
}

\section{Nikša Dubreta :: Karlo Lugarić}

IZVORNI ZNANSTVENI RAD / DOI: 10.20901/ms.12.23.6 / PRIMLJENO: 23.7.2020.

SAŽETAK U članku se medijska reprezentacija novih psihoaktivnih supstanci razmatra primjenom teorije društvene reprezentacije. Budući da nove psihoaktivne supstance u hrvatskom društvenom kontekstu predstavljaju relativno nepoznat fenomen, u članku je obrazložena analitička upotrebljivost komunikativnih mehanizama društvene reprezentacije koji se mogu koristiti u istraživanju medija. S tom svrhom provedena je analiza sadržaja priloga o novim psihoaktivnim supstancama koji su u razdoblju od sedam godina objavljeni na odabranim hrvatskim internetskim portalima. Rezultati su pokazali da imenovanje, emocionalno sidrenje i emocionalno upredmećivanje predstavljaju ključne komunikativne mehanizme u procesu medijski posredovane društvene reprezentacije novih psihoaktivnih supstanci. Analiza implicitnih temeljnih vrijednosti sadržanih u objavljenim člancima pokazala je da se isticanjem zdravstvenih rizika i slabosti u djelovanju društvene kontrole, nove psihoaktivne supstance konvencionaliziraju preko teme "društvo bez droga". UPREDMEĆIVANJE, UPOTREBA DROGA

Bilješka o autorima

Nikša Dubreta :: Sveučilište u Zagrebu, Fakultet strojarstva i brodogradnje :: niksa.dubreta@fsb.hr

Karlo Lugarić :: karlo.lugaric@yahoo.com 


\section{UVOD}

Pojava novih i nepoznatih supstanci karakterizira cjelokupnu modernu epohu tijekom koje su globalizirane i povećane proizvodnja, trgovina i upotreba niza psihoaktivnih proizvoda (Jamieson, 2001; Wallerstein, 1986). Prevladavajući obrazac u tom procesu najčešće se zasnivao na nekoliko faza, počevši od razmatranja mogućnosti medicinske primjene novih tvari, preko širenja nekontrolirane upotrebe iz užitka, nerijetko praćene ovisnošću i zdravstvenim tegobama, do pokušaja regulacije već etablirane upotrebe u terminima komercijalizacije i stvaranja sustava legalne trgovine takvim proizvodima (Courtwright, 2001). Razvoji na području medicine, prema Courtwrightu, tijekom 19. stoljeća ubrzali su proces širenja upotrebe psihoaktivnih sredstava i stvorili svojevrstan „sintetički psihoaktivni okvir" u kojem su se etablirale danas ilegalne droge poput heroina i kokaina. Premda su ubrzani razvoji na području farmakologije na prijelazu u 20 stoljeće rezultirali identificiranjem novih psihoaktivnih sastojaka (ibogain, harmin i harmalin, MDA, a 1943. i LSD), sve do pred kraj 20. stoljeća taj okvir ostao je relativno jednostavan, sa spomenutim etabliranim drogama u njegovu središtu.

Krajem 20. stoljeća proces sintetizacije novih tvari ponovno se intenzivira, najprije u proizvodnji i rekreativnoj upotrebi ecstasija (MDMA), ketamina i gama-hidroksibutirata $(\mathrm{GBH})$, a potom se u 21. stoljeću dodatno ubrzava ilegalnom proizvodnjom niza novih psihoaktivnih kemijskih spojeva koji u značajnijoj mjeri počinju zauzimati niše u postojećim tržištima rekreativne upotrebe droga (Reuter i Pardo, 2016). Ured Ujedinjenih naroda za drogu i kriminal promovirao je naziv "nove psihoaktivne supstance“ (new psychoactive supstances, u daljnjem tekstu: NPS) koje se definiraju kao nove narkotičke i psihotropne droge koje „nisu pod kontrolom konvencija Ujedinjenih naroda o drogama, ali koje mogu predstavljati javnozdravstvenu prijetnju usporedivu onoj koju predstavljaju supstance već navedene u tim konvencijama" (Council Decision, 2005/387/JHA, prema Pirona i sur., 2016). Kako na međunarodnoj tako i na nacionalnim razinama, politika prema drogama ubrzo se suočila s nemogućnošću da na učinkovit način prati snažnu dinamiku i kompleksnost NPS-a (Seddon, 2014). Usto, razvoj interneta na kojem je moguće pronaći informacije o kemijskim sintezama s ciljem ilegalne proizvodnje, globaliziranim kripto-tržištima i forumima za razmjenu znanja i iskustava, omogućio je da proizvodnja, trgovina i upotreba kontinuirano ostaju u prednosti pred postojećim regulativama (Seddon, 2014). Prema Sustavu ranog upozorenja Europske unije (EU EWS) broj novih prijavljenih tvari ubrzano je rastao od 2005. godine (Lugarić, 2018) kada je registrirano 13 novih supstanci, a vrhunac je doživio u 2014. godini u kojoj je registrirana 101 nova psihoaktivna supstanca. Nakon toga broj novih godišnje registriranih supstanci opao je na 51 u 2017. i 55 u 2018. godini (EMCDDA, 2019).

U službenim izvješćima kao i u većini istraživanja NPS se razmatra kroz tri skupine. Prvu i najveću skupinu čine sintetički kanabinoidi namijenjeni legalnoj prodaji, nerijetko kroz proizvode koji se promoviraju kao dodaci mirisima i osvježivači zraka i odražavaju povećanu potražnju za kanabisom (Reuter i Pardo, 2016). Drugu skupinu čine sintetski katinoni, koji se nerijetko koriste kao zamjena za ecstasy (MDMA), amfetamin i kokain i 
prodaju se u obliku „soli za kupanje“ (Favretto i sur., 2013). Napokon, opioidi poput fentanila čine treću skupinu novih psihoaktivnih supstanci, prodaju se kao zamjena za heroin i predstavljaju posebnu prijetnju zdravlju.

Prevalenciju upotrebe novih psihoaktivnih supstanci u Europi još uvijek nije jednostavno utvrditi s obzirom na varijacije u uzorcima i primijenjenim metodologijama (Pirona i sur., 2016). Stopa isprobavanja 2014. godine iznosila je do $8 \%$ među odraslim osobama u pojedinim zemljama Europske unije (EMCDDA, 2015), uz niz varijacija s obzirom na uže definirane dobne skupine i vrste NPS-a. Razine konzumacije novih psihoaktivnih supstanci na planu procjene godišnje stope prevalencije u Europi sveukupno su niske i u odrasloj populaciji kretale su se od 0,1 \% u Norveškoj 2019. godine, do 3,2 \% u Nizozemskoj 2016. (EMCDDA, 2019). Rezultati hrvatskog istraživanja na općoj populaciji (Glavak Tkalić, 2018) također su upozorili na nisku prevalenciju novih psihoaktivnih supstanci - probalo ih je 2,7 \% odrasle populacije, a 1,3\% tijekom protekle godine. Najveći dio isprobavanja i korištenja odnosi se na sintetičke kanabinoide, a upotreba je najizraženija među mladim osobama (EMCDDA, 2019; Glavak Tkalić, 2018). Kada se fokus istraživanja pomakne od opće populacije prema ciljanim skupinama, poput redovitih posjetitelja noćnih klubova ili osoba koje injektiraju droge, stope prevalencije su veće i na takve skupine odnose se povećane razine zabrinutosti, poglavito kada je riječ o problematičnim oblicima upotrebe i pripadajućim štetama (EMCDDA, 2019; Pirona i sur., 2016).

NPS još uvijek predstavljaju relativnu nepoznanicu na planu 'javnog znanja'. Njihova upotreba praćena je moralnom indignacijom (Young, 1972) koja se i inače intenzivira u razdobljima pojave novih droga (Forsyth, 2001; Goode, 2008; Goode i Ben-Yehuda, 1994). Pritom, uloga medija istaknuta je u terminima artikuliranog, a nerijetko i ideološkog oblikovanja ideja povezanih s drogama (Kordić i sur., 2017).

U istraživanjima medijske reprezentacije NPS potvrđeni su raznoliki utjecaji na šire kolektivne predodžbe, trendove u upotrebi i zaokrete u službenim politikama (Alexandrescu, 2018). Miller i sur. (2014) utvrdili su da je medijsko izvještavanje o sintetičkim kanabinoidima i "solima za kupanje" u SAD-u u razdoblju od 2005. do 2013. godine bilo tijesno povezano s poduzetim zakonskim mjerama i njihovom zabranom. Istraživanja prikaza NPS-a u mađarskim online medijima pokazala su prevladavajući pristup prema kojem se radi o problemima "drugih", pretežno socioekonomski depriviranih ruralnih i gradskih manjinskih skupina, pri čemu su korisničke informacije u potpunosti izostavljene (Kassai i sur., 2016; Pelbat i sur., 2016). Swalve i DeFoster analizirale su medijske prikaze NPS-a pri izvještavanju o nasilničkim sukobima u Miamiju 2012. godine izdvajajući, kao dominantne, senzacionalističke opise incidenata i s njima povezanih droga, opise upotrebe "soli za kupanje" kao epidemije i zahtjeve za oštrijim kažnjavanjem njihovih korisnika (Swalve i DeFoster, 2016). Napokon, Alexandrescu je u komparativnoj analizi britanskih i rumunjskih medija upozorila na klasnu pristranost u izvještavanju o NPS s dominantnim portretiranjem korisnika iz srednje klase kao „naivnih“, ali inherentno vrijednih pripadnika društva za razliku od prikaza „prijezira vrijednih“ pripadnika marginaliziranih skupina, u medijima nerijetko zahvaćenih kroz termine zaraze i prijetnje društvu (Alexandrescu, 2018). 
Budući da NPS u Hrvatskoj također predstavljaju nov fenomen o kojem se malo zna, smatrali smo da analiza njihove medijske reprezentacije omogućuje identificiranje dominantnih predodžbi koje mogu predstavljati konstitutivne elemente u formiranju 'javnog znanja' o tom fenomenu. Pritom smo smatrali da je u dijelu spomenutih studija utjecaj medija kvalificiran kao pretežno hegemonijski, a na planu dosega uglavnom kao determinirajući čimbenik u oblikovanju širih društvenih i zdravorazumskih predodžbi, što nije uvijek podložno provjeri (Skoko i Vrdoljak, 2018). Oslonili smo se na teoriju društvene reprezentacije kao mogući okvir za razmatranje medijski posredovanih predodžbi o NPS-u u kojem medijski prikazi predstavljaju tek jedan od čimbenika u procesu konvencionalizacije nekog novog i nepoznatog fenomena s kojim se društvena zbilja nerijetko oblikuje kroz osjećaje tjeskobe, straha i neizvjesnosti.

\section{TEORIJA DRUŠTVENE REPREZENTACIJE}

Koncept društvene reprezentacije zasnovan je u okviru kognitivne socijalne psihologije, a elaboriran je u radovima Sergea Moscovicija. Među brojnim Moscovicijevim određenjima društvene reprezentacije moguće je izdvojiti sljedeće u kojem ona označava:

sustav vrijednosti, ideja i praksi s dvostrukom funkcijom: prvo, da uspostavi poredak koji će omogućiti pojedincima da se orijentiraju u svojem materijalnom i društvenom svijetu i da njime ovladaju; i drugo, da omogući komunikaciji da zauzme mjesto među članovima društva dajući im kod za društvenu razmjenu, te kod za nedvosmisleno imenovanje i klasificiranje različitih aspekata njihovih svjetova i njihovih grupnih povijesti. (Moscovici, 1973, str. xiii, prema Höijer, 2011, str. 5)

Premda Moscovici upućuje na pojam društvene reprezentacije na različite načine, ovisno o kontekstu na koji ga primjenjuje (Liu, 2004), ključne odrednice upućuju na to da se društvena reprezentacija generira u procesu društvene interakcije i komunikacije, kako bi na specifičan način konvencionalizirala objekte, osobe ili događaje s kojima se susrećemo (Lugarić, 2018) i kako bi ih postupno etablirala u terminima distinktivnih i dijeljenih spoznaja (Moscovici, 2000). Budući da neki objekti, osobe i događaji mogu predstavljati novost i nepoznanicu u nekom društvenom kontekstu, društvena reprezentacija predstavlja svojevrsno „prevođenje“ nečega složenog i apstraktnog u korpus "društvenog znanja" putem prilagodbe već etabliranim i prihvaćenim vrijednostima i uvjerenjima (Joffe, 2003).

Stoga, društvenu reprezentaciju Moscovici smatra „preskriptivnom” jer na podlozi već uspostavljenih struktura i tradicije determinira načine na koje članovi društva sagledavaju svijet oko sebe (Moscovici, 2000). Ipak, s obzirom na fragmentiranost suvremenih društava taj determinizam nije neosporiv, što znači da se društvene reprezentacije uspostavljaju, ali i s vremenom mijenjaju u procesu interakcije i komunikacije različitih aktera koji sudjeluju u njihovu formiranju.

Moscovici (2000) spominje dva sociokognitivna komunikativna mehanizma koji generiraju društvenu reprezentaciju - sidrenje i upredmećivanje. Sidrenjem kategoriziramo i 
imenujemo nešto što nam je strano i što ne možemo opisati te ga zbog toga doživljavamo kao nešto nepostojeće i kao prijetnju (Moscovici, 2000). Budući da to rezultira otporom i distanciranjem, prema Moscoviciju, ljudi obično posežu za klasificiranjem i imenovanjem, ponajprije usporedbom uočenog fenomena s već poznatim prototipima za koje se pretpostavlja da ga mogu reprezentirati.

Höijer (2011) uz imenovanje navodi još nekoliko mehanizama sidrenja. Emocionalno sidrenje predstavlja komunikativni mehanizam kojim se, napose u medijima, nov fenomen interpretira upućivanjem na uvriježene emocije poput osjećaja odgovornosti zbog individualnog i kolektivnog sudjelovanja u konzumiranju proizvoda neposredno povezanih s klimatskom krizom. Tematsko sidrenje predstavlja dubinsku strukturu neke društvene reprezentacije, a prema Liu (2004) upućuje na povijesno ukotvljene i kulturno zasnovane antonimije koje nisu uvijek podložne neposrednom opažanju. Moscovici se u tom smislu koristio terminom „temat(i)“, upućujući na temeljne kolektivne ideje koje u specifičnim društvenim okolnostima posreduju u oblikovanju društvenih reprezentacija (Höijer, 2011). Radi se o implicitnim vrijednostima ili načelima koji upravljaju društvenim reprezentacijama i koje u njima tek trebaju biti prepoznate (Liu, 2004, str. 256). Sidrenje u antonimima upućuje na pojavu prema kojoj se davanje smisla nečemu zasniva na sposobnosti kreiranja distinkcija, tj. promišljanja fenomena iz svijeta oko nas u terminima suprotnosti i polariteta (Markova, 2003). Höijer (2011) upućuju na to da su antonimi vidljivi u medijskoj reprezentaciji klimatskih promjena, posebno na planu naglašavanja krivnje i nedužnosti. Napokon, sidrenje putem metafora omogućuje da stvari i fenomeni postanu razumljivima u terminima prenesenog značenja, tj. da ih se prema načelu sličnosti osmisli „kao nešto drugo" (Höijer, 2011, str. 11), već poznato. U slučaju klimatskih promjena planet se pretežno opisuje kao "bolestan“ i kao "sve bliže smrti“. U tom smislu metafore ne samo da naglašavaju ozbiljnost problema već ga istodobno povezuju s našim egzistencijalnim bojaznima (Höijer, 2011).

Upredmećivanje predstavlja drugi komunikativni mehanizam generiranja društvene reprezentacije koji omogućuje da relativno strane i nerazumljive ideje poprime konkretne obrise koji ih povezuju s realnim i opipljivim svijetom. Upredmećivanjem se nešto što je „ispočetka spoznato u nekom intelektualnom i udaljenom univerzumu pred našim očima pojavljuje kao utjelovljeno i dohvatljivo" (Moscovici, 2000, str. 49). Prema Moscoviciju, materijalizacija, odnosno upredmećivanje apstrakcije, inherentna je ljudskoj misli i govoru i omogućuje da ikonička obilježja neke nejasne ideje budu pretočena u koncept ili predodžbu - poput predodžbe u kojoj je Bog predstavljen kao otac i u kojoj nešto nevidljivo trenutno postaje dostupno našem umu i percipirano u terminima konkretne osobe kojoj se možemo izravno obraćati (Moscovici, 2000). Najvažnija značajka upredmećivanja sugerira da materijalizirane slike i predodžbe neke ideje predstavljaju zdravorazumsko i „društveno znanje" o njoj samoj.

Höijer (2011) razmatra dva tipa upredmećivanja: emocionalno upredmećivanje i upredmećivanje putem personifikacije. Prvi uključuje snažnu emocionalnu komponentu poput vijesti koje klimatske promjene upredmećuju u slikama poplava, požara itd. (Höijer, 2011). 
Drugim, personifikacijom, „neke ideje ili fenomeni postaju povezani sa specifičnim ljudima, kao kad, npr. Gandhi personificira nenasilnu političku borbu“ (Höijer, 2011, str. 13). Höijer tvrdi da je povezivanje nečega uz poznate javne ličnosti popularan diskurzivni mehanizam koji se u medijima koristi s ciljem usmjeravanja pozornosti.

Važnost uloge medija u generiranju društvenih reprezentacija nekih, poglavito novih i u terminima rizika raspravljanih fenomena, potvrđena je i u drugim istraživanjima. Kako navodi Joffe (2003), prvi kontakt običnih ljudi s potencijalnim opasnostima ne odvija se isključivo u njihovoj međusobnoj komunikaciji, nego i putem medijski posredovanih vijesti. Pritom, složeno i ekspertno znanje pojednostavljuje se i senzacionalizira uspostavljajući okvir za javne rasprave u kojima pitanja odgovornosti i krivnje bivaju postavljena u prvi plan. Primjerice, analize ranih društvenih reprezentacija sifilisa i AIDS-a pokazuju da su obje bolesti „sidrene kroz smrt, stigmu, nemoralno ponašanje i pravednu kaznu“ (Joffe, 2003, str. 63). Joffe upozorava da pri razmatranju medijski generiranih društvenih reprezentacija treba voditi računa o ograničenosti njihova utjecaja na laičko znanje, kao i o tome da je vrijednosna dimenzija sadržana već u tzv. ekspertnom znanju koje prethodi medijskom inventoriju. Ipak, u procesu transformacije reificiranog znanstvenog univerzuma u laičko mišljenje, mediji predstavljaju jedan od najvažnijih aktera i kao takvi naznačeni su već u Moscovicijevim radovima u kontekstu potrebe za „rekonstitucijom“ zdravorazumskog i na emocijama zasnovanog razumijevanja niza novih i s rizicima povezanih fenomena (Moscovici, 1984).

Medijski prikazi NPS-a predstavljaju važan, premda ne i jedini, aspekt generiranja društvene reprezentacije fenomena koji se u suvremenim društvima pojavljuje kao nov, otprije nepoznat u javnom diskursu, potencijalno opasan na planu zdravlja i podložan različitim tumačenjima. Gotovo svi spomenuti mehanizmi generiranja društvene reprezentacije upotrebljivi su za istraživanje medijske reprezentacije NPS: od sidrenja u terminima njihova imenovanja, emocionalno zasnovanih prosudbi o njihovu karakteru i upotrebi, tematskog sidrenja u okvirima postojećih ideoloških i sociokulturnih predodžbi o drogama i društvu, polariziranih stavova i na metaforama zasnovanih prikaza do emocionalnog i na personifikaciji zasnovanog upredmećivanja.

Stoga je osnovni cilj istraživanja bio utvrditi obrasce društvene reprezentacije NPS u dijelu hrvatskih medija. Usto, željeli smo utvrditi koji su komunikativni mehanizmi u najvećoj mjeri zastupljeni u društvenoj reprezentaciji NPS-a u odabranim medijima. Napokon, kvalitativnom analizom nastojali smo razabrati elemente dubinske strukture analiziranih članaka koje se u referentnoj literaturi obično zahvaća terminom tema (Liu, 2004; Moscovici, 1984). Istraživanje je provedeno zaključno sa srpnjem 2018. godine, zahvaćajući razdoblje od nekoliko godina tijekom kojih je izvještavanje o NPS-u postalo učestalije. Smatrali smo da teorija društvene reprezentacije omogućuje uvid u obrasce medijskog posredovanja u procesu oblikovanja "društvenog znanja” o NPS. 


\section{METODA I UZORAK}

U istraživanju smo se koristili kvalitativnom i kvantitativnom analizom sadržaja priloga koji su o NPS-u objavljeni na odabranim nacionalnim, dnevnim internetskim portalima. Početne kategorije određene su uz upotrebu komunikativnih mehanizama sidrenja i upredmećivanja koje je u istraživanju društvene reprezentacije klimatskih promjena razvila Höijer (2011). To su: imenovanje, emocionalno sidrenje, sidrenje u metaforama, sidrenje u antonimima, emocionalno upredmećivanje i upredmećivanje putem personifikacije. Tijekom probne analize kodiranjem je razvijen dio preliminarnih tema, a uključen je i dodatni komunikativni mehanizam "sidrenje u etabliranim drogama" s namjerom da utvrdimo u kojoj mjeri imenovanje NPS korespondira s njihovom taksonomijom prema kojoj ih se i promatra kao zamjenu za otprije poznate ilegalne droge.

Jedinice analize čine članci o NPS-u koji su putem ključnih riječi („droga”, „, nove droge”, „nove psihoaktivne supstance" i niza uličnih i službenih naziva proizvoda) prikupljeni na tražilicama odabranih internetskih portala. Jedinice analize zahvaćaju tekstualni sadržaj i naslove tih članaka i ne uključuju popratne ilustracije i komentare čitatelja. Spomenuti pojmovi bilježeni su i sa svrhom kodiranja jer su procijenjeni kao relevantni za razvrstavanje u komunikativne mehanizme i jer u generičkim terminima upućuju na NPS (nove psihoaktivne supstance, nova droga i sl.) ili predstavljaju njihove ulične nazive ("Galaxy“,

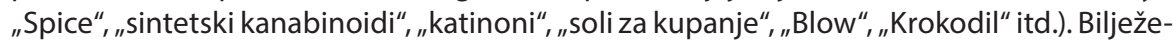
ni su i pojmovi koji izazivaju emocije (smrt, patnja, zdravlje), pojmovi koji upućuju na neke uključene društvene kategorije (mladi, roditelji, službe društvene kontrole, stručnjaci) itd. Kontekstualne jedinice sastojale su se od tekstualnog okvira unutar kojeg se iscrpljuje opis jedinica bilježenja. Prema Krippendorffu (2004), jedna rečenica može biti promatrana kao kontekstualna jedinica, premda je češće slučaj da se opis nekog fenomena može razabrati kroz odlomke s više rečenica, a u nekim slučajevima i kroz cjelovit tekst. To se potvrdilo i u ovom istraživanju jer su se rečenice, kao kontekstualne jedinice u odnosu na odlomke, pojavile u 40 \% slučajeva, što ne začuđuje ako se ima u vidu da svaki od 77 članaka ima naslov u formi rečenice koja se može promatrati kao jedinica u kojoj je sadržan pripadajući kontekst (npr. naslov članka objavljenog u Večernjem listu 29. 3. 2014.: „Majka i sin u Osijeku prodavali drogu krokodil od koje se raspada cijelo tijelo“). U ostalim slučajevima odlomci su promatrani kao prikladan okvir za definiranje kontekstualne jedinice.

Takav pristup rezultirao je potrebom da se određeni pojmovi smjeste u dvije kategorije, tj. u preliminarne teme. U 62 slučaja radilo se o formulaciji koja paralelno može biti promatrana kao imenovanje i kao sidrenje u antonimima (npr. nova droga). Preklapanje sidrenja u etabliranim drogama i sidrenja u antonimima evidentirano je 36 puta (npr. jače od heroina), a preklapanje emocionalnog sidrenja i emocionalnog upredmećivanja 17 puta (npr. preminuli dječak). Ostala preklapanja evidentirana su dva ili manje puta (Lugarić, 2018).

Dubinska struktura na kojoj se zasniva društvena reprezentacija NPS-a u analiziranim člancima razvijena je putem kvalitativne analize, provedene naknadno i zasebno. Radi se o temama koje su implicitno ugrađene u društvenu reprezentaciju nekog fenomena 
i koje predstavljaju „historijski ukotvljene pretpostavke, kulturno prepoznatljive antonimije i dublju logiku društvene misli“ (Liu, 2004, str. 255). One prožimaju i podupiru glavne aspekte društvene reprezentacije i reflektiraju implicitne i temeljne vrijednosti povezane s društvenom reprezentacijom nekog fenomena u specifičnom povijesnom kontekstu šireg društva (Markova, 2015). To nisu teme koje obično povezujemo s tematskom analizom u kvalitativnim istraživanjima i za koje se u ovom radu koristimo terminima „pragmatične manifestacije“ (Liu, 2004) i „preliminarne teme“, već temeljne vrijednosti koje stoje u njihovoj podlozi. S obzirom na to da smo namjeravali uočiti temeljne vrijednosti preliminarnih tema (ili aspekata) društvene reprezentacije NPS-a u analiziranim člancima, smatrali smo da odgovaraju temeljnim vrijednostima koje okružuju diskurs o svim drogama. To je zacrtalo smjer ponovljenog pristupa člancima, sada referiranjem na kulturno prepoznatljive antonimije u pretežno emocionalnom sidrenju i upredmećivanju, kao i u sidrenju u antonimima i metaforama.

Kvantitativnu analizu sadržaja proveo je jedan, a kvalitativnu analizu sadržaja drugi autor. U oba slučaja pouzdanost se zasniva na stabilnosti (test-retest, odnosno višekratno čitanje i provjeravanje jesu li zabilježeni pojmovi na koherentan način razvrstani u kategorije i njihove preliminarne teme) koja predstavlja početni, ali svakako ne i najprikladniji kriterij pouzdanosti u analizama sadržaja koju provodi više istraživača.

Istraživanje je provedeno na portalima - 24sata, Večernji list i Jutarnji list - koje, u vrijeme neposredno prije prikupljanja empirijskog materijala (lipanj - rujan 2018.), istraživačke agencije Ipsos Puls i gemiusAudience navode kao najčitanije hrvatske portale s tiskanim izdanjem (Lugarić, 2018). Prema istraživanju Ipsos Pulsa iz ožujka 2017. (Skoko i Vrdoljak, 2018) utvrđen je porast čitanosti online portala u svim dobnim skupinama uz istodobno opadanje čitanosti dnevnih novina u usporedbi s čitanošću novinskih portala. S druge strane, Kordić i sur. (2017) u istraživanju medijske reprezentacije ovisnosti, dnevna tiskana izdanja promatraju kao jedan od važnih izvora informacija koji tradicionalno preferira starija populacija. Stoga smo se odlučili da se u ovom istraživanju koncentriramo na najčitanije nacionalne, dnevne news portale koji imaju i tiskano izdanje.

Pojašnjavajući metriku gemiusAudiencea, Skoko i Vrdoljak navode Jutarnji.hr i Vecernji.hr kao news portale koji su u travnju 2018. imali najveći doseg. Prema prikazu dnevne posjećenosti velikih news portala za 10. travnja 2018., u kojem su Gemius i Ipsos Dotmetrics kombinirali podatke jer se dio portala ne pojavljuje istodobno u istraživanjima obiju agencija, Bernik (2018) je spomenutim portalima pridružio i 24sata.hr. Spomenute metrike svakako su ograničene jer su usmjerene pretežno na razvoj prostora za oglašavanje i ne omogućuju zaključivanje o tome koliki je stvarni utjecaj nekog sadržaja. Međutim, u vrijeme provođenja ovog istraživanja bolja metrika nije bila dostupna (Skoko i Vrdoljak, 2018).

Pretragom je utvrđeno da se kontinuitet objavljivanja članaka na spomenutim news portalima može identificirati s početkom u 2011. godini, nakon koje, premda donekle neravnomjerno, broj objavljenih članaka kontinuirano raste sve do sredine 2018. godine kada je istraživanje provedeno. Nakon pretrage 9 članaka nije se koristilo jer su bili istovjetni onima ranije objavljenima i uvrštenima u analizu. Članci u kojima se govori o 
istom događaju, osobama ili stvarima, a razlikuju se u sadržaju, uključeni su u istraživanje. Uzorak obuhvaća 15 članaka iz prvih šest mjeseci 2018., 20 članaka iz 2017., 15 članaka iz 2016., 14 članaka iz 2015., 4 članka iz 2014., 6 članaka iz 2013., 1 članak iz 2012., te 2 članka iz 2011. godine. Od toga su 32 članka preuzeta s portala 24sata, 19 s Jutarnjeg lista i $26 \mathrm{~s}$ Večernjeg lista. Ukupan broj analiziranih članaka je 77 (Lugarić, 2018). Ukratko, populaciju koja je zahvaćena istraživanjem i zaključcima čine članci s odabranih internetskih portala koji imaju i tiskano izdanje.

\section{REZULTATI ISTRAŽIVANJA}

Tijekom analize razvijena je ukupno 31 preliminarna tema putem kojih se manifestira društvena reprezentacija NPS-a. S ciljem preglednijeg predstavljanja rezultata taj broj preliminarnih tema redefiniran je na sljedeći način: 13 preliminarnih tema sažeto je u 5 novih, nešto sveobuhvatnijih, uz preimenovanje i očuvanje analitičke i teoretske konzistentnosti. Sažimane su isključivo one preliminarne teme koje se nalaze unutar komunikativnih mehanizama jer se pokazalo da sažimanjem i namjerom za sveobuhvatnijim prikazom ne gube na deskriptivnosti. U sklopu mehanizma emocionalnog upredmećivanja dvije početne preliminarne teme: „opisi prizora predoziranja i smrti“ $\mathrm{i}$ „opisi konzumiranja neke supstance" integrirane su u jednu sveobuhvatniju koju je moguće vidjeti u Tablici 1 pod nazivom opisi konzumiranja, predoziranja i smrti. U sidrenju putem metafora 2 početne preliminarne teme (opisi supstance i upotreba supstance) integrirane su u jednu - opisi supstanci i njihove upotrebe. $\mathrm{U}$ istom komunikativnom mehanizmu druge 2 početne preliminarne teme (opis događaja i brza pojava NPS) integrirane su u jednu - opisi događaja $i$ širenje NPS- $a$. U sklopu mehanizma sidrenja u antonimima 4 početne preliminarne teme (vrijeme potrebno za učinak, jačina, duljina djelovanja supstance i štetnost) sažete su u jednu sveobuhvatniju: djelovanje supstance. Napokon, u tom istom komunikativnom mehanizmu 3 početne preliminarne teme (prepoznatljivost, zahtjevnost nabave supstance i cijena supstance) integrirane su u jednu pod nazivom dostupnost NPS-a.

Provedeni postupak vidljiv je u konačnom prikazu rezultata koji sadrži 5 mehanizama sidrenja i 2 mehanizma upredmećivanja s ukupno 23 preliminarne teme društvene reprezentacije NPS (Tablica 1).

Tablica 1. Preliminarne teme u komunikativnim mehanizmima prema broju jedinica bilježenja

\begin{tabular}{lll} 
Sidrenje u etabliranim drogama & N & $\%$ \\
Marihuana i hašiš & 67 & 29 \\
Heroin i morfij & 57 & 24 \\
Kokain i crack & 15 & 6 \\
Duhan i alkohol & 34 & 15 \\
"Speed", amfetamini & 9 & 4 \\
Etablirane droge općenito & 24 & 10 \\
Ecstasy, MDMA i LSD & 27 & 12 \\
\hline
\end{tabular}




\begin{tabular}{lll}
\hline Sidrenje putem metafora & N & $\%$ \\
\hline Opisi supstanci i njihove upotrebe & 15 & 27 \\
Opisi događaja i širenje NPS & 6 & 11 \\
Znanstvena fantastika & 35 & 62 \\
\hline Emocionalno sidrenje & $\mathbf{N}$ & $\%$ \\
\hline Smrtna opasnost & 191 & 42 \\
\hline Zdravstveni problemi & 265 & 58 \\
\hline Imenovanje & $\mathbf{N}$ & $\%$ \\
\hline Ulični i sekundarni nazivi supstanci & 229 & 34 \\
\hline Službeni nazivi i taksonomije & 317 & 47 \\
\hline Proizvodi & 123 & 19 \\
\hline Emocionalno upredmećivanje & $\mathbf{N}$ & $\%$ \\
\hline Opisi konzumiranja, predoziranja i smrti & 53 & 18 \\
\hline Djeca, maloljetnici, adolescenti & 175 & 59 \\
\hline Članovi obitelji i bliske osobe & 50 & 17 \\
\hline Siromašni i mentalno bolesni ljudi & 17 & 6 \\
\hline Upredmećivanje putem personifikacije & $\mathbf{N}$ & $\%$ \\
\hline Glazbenici/glumci & 72 & 100 \\
\hline Sidrenje u antonimima & $\mathbf{N}$ & $\%$ \\
\hline Djelovanje supstance & 145 & 37 \\
\hline Dostupnost NPS & 172 & 44 \\
\hline Zakonske odrednice & 74 & 19 \\
\hline
\end{tabular}

Najveći broj preliminarnih tema (7) razvijen je u mehanizmu „sidrenja u etabliranim drogama", a najveći je broj jedinica bilježenja evidentiran u komunikativnom mehanizmu sidrenja pod nazivom „imenovanje“. To upućuje na to da se na planu „imenovanja“, uz upućivanje na njihove ulične nazive, službene taksonomije i same proizvode, NPS najčešće, s ciljem pojašnjavanja, povezuje s drogama čije učinke oponašaju (sidrenje u etabliranim drogama). To je povezivanje u najvećem broju slučajeva bilo konzistentno. Osim „sidrenja u etabliranim drogama“ najveći broj preliminarnih tema (4) razvijen je na planu „emocionalnog upredmećivanja“ koje sugerira različite, ali pretežno emocionalno zaokružene obrasce povezivanja NPS s njima inherentnim opasnostima i rizicima. Fokus reprezentiranja je na opasnostima za mlade osobe, a ta usredotočenost emocionalnog upredmećivanja na pripadnike društvene kategorije mladih u osnovi reflektira dugotrajnost jednog od ključnih aspekata moralne indignacije (Young, 1972) nad upotrebom droga u cjelini i u slučaju društvene reprezentacije NPS-a u ovom istraživanju ne ostavlja puno prostora za dodatno društveno posredovano razvrstavanje. Premda su pripadnici marginalnih skupina (siromašni, mentalno bolesni i beskućnici) s obzirom na emocionalno 
korištene obrasce uvršteni u istu kategoriju, mahom je bila riječ o člancima koji prenose vijesti o posljedicama upotrebe NPS u Rusiji, Velikoj Britaniji i SAD-u. Ostali komunikativni mehanizmi iz Tablice 1 zahvaćeni su s 3 ili manje preliminarnih tema.

Svi komunikativni mehanizmi potom su rangirani s obzirom na broj i postotak pripadajućih jedinica bilježenja. U Tablici 2. vidljivo je da sidrenje kroz „imenovanje“ predstavlja pojedinačan komunikativni mehanizam koji se najčešće koristi u društvenoj reprezentaciji NPS-a i identificiran je u 30 \% jedinica bilježenja.

Tablica 2. Komunikativni mehanizmi prema broju jedinica bilježenja

\begin{tabular}{lll} 
Komunikativni mehanizmi & N & $\%$ \\
Imenovanje & 669 & 30 \\
Emocionalno sidrenje & 456 & 21 \\
Sidrenje u antonimima & 391 & 18 \\
Emocionalno upredmećivanje & 295 & 14 \\
Sidrenje u etabliranim drogama & 233 & 11 \\
Upredmećivanje putem personifikacije & 72 & 3 \\
Sidrenje putem metafora & 56 & 3 \\
Ukupno & $\mathbf{2 1 7 2}$ & 100 \\
\hline
\end{tabular}

Emocionalno sidrenje evidentirano je u 21 \% jedinica bilježenja, nešto manje evidentirani su sidrenje u antonimima (18\%), emocionalno upredmećivanje (14\%) i sidrenje u etabliranim drogama (11\%), a upredmećivanje putem personifikacije kao i sidrenje putem metafora evidentirano je u 3 \% jedinica bilježenja.

Obje tablice omogućuju rudimentarni pregled zastupljenosti komunikativnih mehanizama i pripadajućih preliminarnih tema koji u osnovi potvrđuje Moscovicijeve navode o imenovanju kao važnom mehanizmu sidrenja i generiranja društvene reprezentacije nekog novog i nepoznatog fenomena. Ako mu pridružimo mehanizam sidrenja u etabliranim drogama, uvažavajući da reference na već poznate ilegalne droge također predstavljaju svojevrsno „pojašnjavajuće“ imenovanje, tada taj komunikativni mehanizam zauzima ključno mjesto u generiranju društvene reprezentacije NPS-a i moguće ga je razabrati u ukupno 41 \% jedinica bilježenja. Kad na isti način objedinimo komunikativne mehanizme emocionalnog sidrenja i emocionalnog upredmećivanja jer su usmjereni na osjećaje straha, štetnosti NPS ili na osjećaje empatije prema pojedinim društvenim kategorijama s kojima se upotreba NPS najčešće povezuje, tada oni slijede neposredno za imenovanjem i obuhvaćaju $35 \%$ jedinica bilježenja u analiziranim člancima.

Također, pokazalo se da su identificirane preliminarne teme u komunikativnim mehanizmima u svakom članku međuupućene. One se gotovo uvijek pojavljuju istodobno, a termin „nova droga“ predstavlja najčešću inačicu službenog određenja koja na planu imenovanja reprezentira uglavnom sintetičke kanabinoide i sintetičke opioide. 
Raspodjela komunikativnih mehanizama među portalima odgovara njihovu ranije opisanom ukupnom rangu. $U$ tablici 3 vidljivo je da je imenovanje relativno podjednako zastupljeno u Večernjem listu i u 24sata (33\% i 32\%), a nešto manje u Jutarnjem listu (28 \%). Emocionalno sidrenje najzastupljenije je u Jutarnjem listu (25\%), a nešto manje u Večernjem listu (18\%) i u 24sata (20\%). Sidrenje u antonimima više je vidljivo u Večernjem listu (23\%), a sidrenje u etabliranim drogama najmanje je zastupljeno u 24sata (9\%). 24sata u odnosu na preostala dva portala nešto više emocionalno upredmećuje NPS (15\%), a metafore su u podjednakom omjeru zastupljene u sva tri portala. Premda se analizirani portali razlikuju u uređivačkoj politici i izvještavanju, pri čemu se 24 sata obično promatra kao tabloid (Kordić i sur. 2017), raspodjela komunikativnih mehanizama iz Tablice 3. ne nudi konzistentne nalaze za raspravu o jasnim razlikama u stilu izvještavanja, a tabloidnost ovdje nije svojstvo koje bi se nedvosmisleno moglo pripisati jedino portalu 24 sata.

Tablica 3. Raspodjela komunikativnih mehanizama među portalima prema jedinicama bilježenja

\begin{tabular}{lllll} 
& Jutarnji list & Večernji list & 24sata & $\begin{array}{l}\text { Prosjek za } \\
\text { sve portale }\end{array}$ \\
\hline Imenovanje & $28 \%(168)$ & $33 \%(184)$ & $32 \%(317)$ & $31 \%$ \\
Emocionalno sidrenje & $25 \%(150)$ & $18 \%(101)$ & $20 \%(205)$ & $21 \%$ \\
Sidrenje u antonimima & $14 \%(89)$ & $23 \%(131)$ & $17 \%(171)$ & $18 \%$ \\
Sidrenje u etabliranim drogama & $13 \%(75)$ & $11 \%(60)$ & $9 \%(98)$ & $11 \%$ \\
Emocionalno upredmećivanje & $12 \%(70)$ & $12 \%(70)$ & $15 \%(155)$ & $13 \%$ \\
$\begin{array}{l}\text { Sidrenje u metaforama } \\
\text { Upredmećivanje putem }\end{array}$ & $3 \%(17)$ & $3 \%(11)$ & $3 \%(28)$ & $3 \%$ \\
personifikacije & $5 \%(30)$ & $1 \%(3)$ & $4 \%(39)$ & $3 \%$ \\
\hline
\end{tabular}

Članci najčešće počinju opisima događaja (42 članka) u kojima se uz sâm opis upućuje i na službene i ulične nazive proizvoda i supstanci. Smrt, umiranje, ozbiljni zdravstveni problemi (emocionalno sidrenje) i u nešto manjem dijelu djelovanje policije i zapljene predstavljaju glavne motive u opisima događaja. Akteri u početnim opisima u najvećem su dijelu mladi (39 članaka), što odgovara emocionalnom upredmećivanju, a u jednom manjem dijelu globalno poznate osobe iz popularne kulture povezane s upotrebom NPS (upredmećivanje putem personifikacije). Sidrenje u pretežno zastrašujućim metaforama („zaleđenost krvi u žilama“, „najgora noćna mora“ i sl.) u većini je članaka bilo sporadično, zabilježeno je njih 11 koje su evidentirane 56 puta u 19 članaka. Najvećim dijelom metafore su zabilježene u člancima iz 2017. i 2018. o posljedicama upotrebe sintetičkog kanabinoida pretežno u većim britanskim gradovima, a najčešće su se koristile metafore „zombi“ (19 puta) i „živi mrtvaci“ (7 puta). Tako je u članku s portala 24sata (1. 9. 2017.) u opisu događaja moguće identificirati sidrenje u metaforama koje je praćeno imenovanjem, emocionalnim sidrenjem i upredmećivanjem te sidrenjem u antonimima: „Zora živih mrtvaca: Ova droga opasnija je od heroina i cracka. Ulicama Velike Britanije hoda sve više 'zombija'. Tako nazivaju ovisnike o sintetičkoj drogi poznatoj kao 'spice' čije su posljedice jače od onih koje ostavljaju heroin i crack." 
Pojašnjavajući dijelovi u 38 članaka bave se službenim nazivima i taksonomijama. NPS su sidrene putem analogije s etabliranim drogama i uspoređivanjem jačine njihovih učinaka, definiranjem zakonskih odredbi, zahtjevnosti nabave i cijene (sidrenje u antonimima). Primjerice, u članku „Nova droga hara Rusijom. Opasnija i jeftinija od heroina“ (Večernji list, 20. 12. 2017.) pojašnjenje "soli za kupanje“ kombinira elemente imenovanja, emocionalnog upredmećivanja, sidrenja u antonimima i sidrenja u etabliranim drogama:

Konzumiranje te supstance izaziva uzbuđenje, halucinacije, psihozu, suicidalne misli i srčani udar. Nova droga može se progutati, pušiti ili ušmrkavati, ali najjači udar, kao i kod drugih droga, ima ubrizgavanjem iglom u venu. Posebno je zabrinjavajuće jer je 'sol' opasnija i jeftinija od heroina.

Kvalitativna analiza dubinske strukture društvene reprezentacije NPS-a u odabranim medijskim napisima omogućila je identificiranje teme "društvo bez droga“ koja reflektira dominantne i kolektivne ideje ili obrasce značenja u vezi s pojavom i širenjem NPS-a u Hrvatskoj. Kao ideološki obrazac tema "društva bez droga“ zasnovana je na legalističkim propozicijama i upućuje na društvo bez ilegalnih droga. Dijelom je zasnovana na antonimijskim propozicijama ljudskog mišljenja, a u člancima je prepoznata kao temeljni koncept u emocionalnom sidrenju i upredmećivanju te sidrenju u metaforama i antonimima. Ta tema sadrži dva dominantna motiva koji se podudaraju s uvriježenim i kulturno zasnovanim predodžbama o svim ilegalnim drogama: štetnost NPS-a za zdravlje njihovih konzumenata i prijetnju normativnim konturama društva koje proizlaze iz njihove raširene upotrebe (Tablica 4.).

Tablica 4. Dubinska struktura društvene reprezentacije NPS

\begin{tabular}{|c|c|c|c|}
\hline Tema „društvo bez droga“ & Jedinice bilježenja & $\mathrm{N}$ & $\%$ \\
\hline Inherentna štetnost NPS & & 201 & 57 \\
\hline Društvena kontrola & & 151 & 43 \\
\hline
\end{tabular}

Prvu pragmatičnu manifestaciju spomenute teme nazvali smo „inherentna štetnost NPS-a" jer kroz semantičke elemente u jedinicama bilježenja vrijednosno korespondira sa širim zdravorazumskim predodžbama o ostalim psihoaktivnim supstancama čiju upotrebu društvo ne odobrava i promatra kao prijetnju zdravlju svojih članova. Štetnost NPS očituje se u svim mehanizmima sidrenja i upredmećivanja. Kada je riječ o imenovanju, zdravstveni rizici opisani su usporedbom s rizicima koji se pripisuju etabliranim ilegalnim drogama, nerijetko uz komparacije koje se koriste antonimima kako bi se uputilo na to da su NPS opasnije i štetnije, čime se implicira već „zdravo za gotovo“ prihvaćena inherentna štetnost svih etabliranih ilegalnih droga. Primjerice, to je vidljivo u članku koji govori o tome da su čak i djelatnici policije izloženi opasnostima predoziranja fentanilom, sintetičkim opijatom i u kojem je komparacija vidljiva već u naslovu - „Nova droga je 50 puta jača od heroina, konzumira se dodirom“ - a dodatno je naglašena u tekstu komentarom djelatnika policije: „Odahnemo svaki put kad nađemo samo heroin ili samo kokain ili samo crack i to je jako tužno" (24sata, 7.11.2017). Na sličan način opasnost i štetnost za zdravlje 
i život koja se pripisuje svim ilegalnim drogama očituje se u upozoravajućem karakteru članaka i elementima emocionalnog sidrenja i upredmećivanja. Termin "smrt“ moguće je identificirati u gotovo svim člancima. Na planu opasnosti i štetnosti za zdravlje i život NPS se povezuju s predoziranjem, opasnim simptomima, smrću, ovisnošću, poremećajima i sl. Primjerice, u članku koji upozorava na moguće štetne posljedice upotrebe sintetskog kanabinoida Blow u Hrvatskoj naveden je niz zdravstveno nepoželjnih simptoma:

Dokazano je da su sintetski kanabinoidi izuzetno toksični i štetni za ljudsku konzumaciju. Diljem Europe bilježi se niz trovanja, od kojih neka čak sa smrtnim ishodom. Simptomi trovanja sintetskim kanabinoidima su ošamućenost, vrtoglavica, ubrzan rad srca, mučnina, povraćanje, bol u prsima, zujanje u ušima, glavobolja, anksioznost, tahikardija i kognitivne teškoće - upozorava Sanja Mikulić. (Jutarnji list, 7. 11. 2017.)

Premda se pojavljuju tek u 8 analiziranih članaka, iskustva konzumenata uklapaju se u dominantan tematski okvir opasnosti za zdravlje i život, a gotovo nigdje nisu izravno izrečena, već ih uglavnom prenose autori članaka ili različite službene osobe: „Konzumenti Spice-a izvještavaju o simptomima koji uključuju ubrzani rad srca, povraćanje, uzrujanost, zbunjenost i halucinacije" (24sata, 28.5.2018). U nekoliko članka bilo je moguće naći suzdržanije prosudbe poput: „Još uvijek nema dovoljno podataka o utjecaju ovih proizvoda na ljudsko zdravlje te razinu toksičnosti. Bez daljnjih analiza teško je utvrditi koliko je ta bojaznost opravdana" (24sata, 28. 5. 2018.). Užitak, kao mogući očekivani i ostvareni učinak upotrebe NPS, naznačen je ukupno tri puta. Ako se i radi o opisanim bihevioralnim ili osjetilnim manifestacijama koje korisnici droga mogu interpretirati kao elemente užitka u konzumiranju droga, one su stavljene u okvir nepoželjnosti odnosno rizičnih posljedica:

Udisanje sintetskog plina djeluje kao halucinogena, ali i stimulativna droga, kombinacija trave i, recimo, ecstasyja. Uz miješanje s alkoholom u glavi se stvara još veći kaos. Omamljujuće djelovanje pri udisanju plina preko balona traje desetak minuta. Za to se vrijeme mladi, kao u usporenom filmu, bacaju čas na lijevu, čas na desnu stranu, dižu ruke, glavu zabacuju prema dolje i vrte se radi boljeg efekta. Tih deset minuta ludila čuju glasove u glavi, a upućeni će reći da to 'strašno prži mozak'. (Večernji list, 8. 7. 2013.)

Drugi aspekt „društva bez droga“ kao dubinske strukture članaka je „društvena kontrola“. Ona je prepoznata kao implicitni ideološki obrazac društvene reprezentacije NPSa kojim se njihova upotreba dovodi u vezu s pitanjem funkcioniranja pripadajućeg normativnog okvira. Radi se o propitivanju postojećih ili sugeriranju poželjnih mehanizama društvene kontrole NPS-a koji predstavljaju dominantan obrazac djelovanja na planu upotrebe etabliranih ilegalnih droga. Kao oblik društvenog djelovanja koji je na formalan i neformalan, kao i prisilan ili kooperativan način usmjeren na prilagodbu društvenim normama (Deflem, 2015), društvena kontrola predstavlja nezaobilazan dio u analiziranim člancima i manifestira se u svim mehanizmima sidrenja i upredmećivanja NPS-a. Ipak, kontrola se najviše provlači kroz emocionalno sidrenje te sidrenje putem imenovanja i sidrenje $u$ antonimima, tj. kroz problematiziranje njihove dostupnosti, trenutnog statusa na 
planu legalnosti i ilegalnosti i trenutnog djelovanja različitih aktera u području formalne i neformalne društvene kontrole.

Legalnost nekih NSP, prije svega sintetičkih kanabinoida, predstavljena je kao sastavni dio problema koji se povezuju s upotrebom NPS-a i s djelovanjem službi društvene kontrole, a njihova zabrana nameće se kao rješenje. Usto, pitanje legalnosti implicitno je sadržano i u prenošenju službenih informacija iz područja društvene politike prema drogama. Sljedeći navod pokazuje da je, uz imenovanje, legalnost NPS-a kao problem u djelovanju službi društvene kontrole sidrena i upotrebom metafora: „Borba s novim drogama slična je održanju trošnog brodića, koji na sve strane propušta vodu, na površini rijeke. Čim zapušite jednu rupu, odnosno detektirate novu drogu, iz laboratorija narkodilera pojavi se druga“ (24sata, 9. 5. 2018.). U 38 članaka evidentirane su formulacije koje se eksplicitno referiraju na problem legalnosti NSP-a i koje upućuju na to da se one "mogu legalno nabaviti“, da im je "olakšan pristup", da "nisu kriminalizirane“, ", ne podliježu zakonskim mjerama“, „prolaze ispod radara tržišnim inspekcijama“ i sl. Pritom, kao objekt od posebne važnosti na planu društvene kontrole, istaknuti su smartshopovi, tj. trgovine u kojima se dio NSP u razdoblju zahvaćenom ovim istraživanjem mogao legalno nabaviti.

Usto, društvena kontrola naznačena je i iskazivanjem potrebe za pojačanom prevencijom i uvođenjem reda. Ovisno o sadržaju i tipu pojedinog članka upozorenja su usmjerena na roditelje da paze na djecu, ljekarnike da obrate pozornost kome što prodaju, vlast da zatvori smartshopove i ukloni legalne NPS-e s tržišta legalnih proizvoda, djecu i učenike da će biti sankcionirani zbog upotrebe NPS-a, nastavnike da strože kontroliraju ponašanje učenika, policiju da bude djelotvornija u svojem djelovanju itd. - što predstavlja već dobro poznat repertoar upozorenja povezanih s kontrolom upotrebe droga u cjelini. Primjerice, usmjerenost na roditelje kao subjekte društvene kontrole i djecu kao njezine objekte najjasnije je izražena u članku posvećenom opasnostima koje sa sobom nosi upotreba sintetičkih kanabinoida i u kojem se roditelje upozorava: „.... da više obrate pozornost što im rade djeca i tko su im prijatelji, da djeci objasne kako nije 'cool' s 13 godina imati cigaretu ili alkohol, da ne trebaju uzimati sve što im se ponudi kako bi bili prihvaćeni u društvu u kojem se nalaze, te da ima pametnijih sredstava relaksacije, poput bavljenja sportom" (24sata, 10. 5. 2018.). S druge strane, striktnija kontrola koja uključuje poželjnost negativnih sankcija odnosi se na reguliranje poslovanja smartshopova koji su izravno spomenuti u 17 članaka:

Takvi su preparati dostupni u 'smart shopovima', vrećica s nekoliko grama prodaje se za stotinjak kuna i može je kupiti tko god hoće. Dijete do 18 godina ne može u trgovini kupiti cigarete i alkohol, ali može ući u 'smart shop' jer je takva droga deklarirana kao osvježivač zraka, baš poput mirisnih biljnih preparata koje stavljamo u ormare s odjećom, a nitko kemijski ne može dokazati da ona to nije. (Večernji list, 10. 5. 2018.)

Premda se među navedenim i u člancima ciljanim akterima formalne i neformalne društvene kontrole može prepoznati dobar dio čitatelja, pojedina upozorenja odnose se na čitateljstvo i javnost u cjelini poput napisa koji upućuju na to da je djelovanje službi (policije i zakonodavca) nemoćno i neuspješno, ili da su te droge lako dostupne. 


\section{ZAKLJUČNA RAZMATRANJA}

Provedena analiza pokazala je da se sidrenje i upredmećivanje pretežno zasnivaju na imenovanju i emocijama kao komunikativnim mehanizmima koji NPS, kao relativno nov i nepoznat fenomen u hrvatskom kontekstu, konvencionaliziraju u smjeru zdravorazumskog znanja. Pritom, Moscovicijeve opaske o klasificiranju kao važnoj dimenziji imenovanja ovdje su se pokazale kao opravdane, posebno u dijelu koji se odnosi na usporedbu novog fenomena s već poznatim prototipovima poput sidrenja u etabliranim drogama.

Imenovanje i klasificiranje popraćeno je učestalim referencama na znanstvene spoznaje koje su u gotovo polovini analiziranih članaka osnažene izjavama stručnjaka. To korespondira s teorijom društvene reprezentacije (Joffe, 2003; Moscovici, 1984) prema kojoj relativno nov i nepoznat fenomen, konceptualiziran u složenom i nerijetko teško razumljivom univerzumu ekspertnog znanja, mediji pojednostavljuju sa svrhom informiranja i šireg zdravorazumskog razumijevanja. Pritom je putem emocionalnog sidrenja i upredmećivanja uspostavljen okvir u kojem je NPS predstavljen kao opasnost i prijetnja zdravlju i životima njihovih konzumenata i ugrađen u proces podizanja društvene osjetljivosti.

Inherentna štetnost NPS-a prepoznata je kao jedna od dviju pragmatičnih manifestacija u analizi teme "društva bez droga" kao dubinske strukture medijskih prikaza koja se podudara sa širim društvenim vrijednostima i dominantnim ideologijama na planu upotrebe droga općenito. $U$ većini članaka popraćena je terminom "smrt“ $i$ upućivanjem na niz problematičnih psihosomatskih simptoma. Kada je riječ o užitku, implicira se da NPS predstavlja neadekvatnu zamjenu za tri osnovne skupine otprije etabliranih ilegalnih droga, pri čemu očekivani učinci koje povezujemo s upotrebom, primjerice marihuane, heroina i kokaina, u slučaju NPS-a ustupaju mjesto onim nepoželjnim.

Druga pragmatična manifestacija teme "društva bez droga“ jest društvena kontrola nad upotrebom NPS-a. Njihova zakonska regulativa u većini članaka predstavlja ključnu poteškoću, a trgovine u kojima se dio njih može kupiti identificirane su kao negativni simboli (poput dilera) koje bi preventivnim djelovanjem društvene kontrole trebalo zatvoriti. Izglednost, pa i poželjnost represivnijeg djelovanja, sadržana je i u upozorenjima upućenim učenicima kao potencijalnim korisnicima i u tvrdnjama o poželjnosti kriminalizacije samih NPS-a. Napokon, ako se sintetske kanabinoide, opasne po zdravlje i život, imenuje i upredmećuje kao legalnu zamjenu za kanabis i kao "stvar“ koja treba biti kriminalizirana, a da se bilo gdje istodobno ne progovori o pravnom statusu kanabisa koji se već dulje vrijeme u samim medijima reprezentira u terminima polemičke društvene reprezentacije (Dubreta, 2005), onda se može govoriti o nekoj vrsti kulturno zasnovanog „refleksa“ kojem je kriminalizacija droga toliko u prvom planu da te dvije "stvari“ - sintetičke kanabinoide i kanabis - ne može dovesti u vezu kroz makar usputno problematiziranje trenutne ilegalnosti kanabisa.

Premda su u većini članaka istaknuti kao ključni akteri upotrebe NPS-a, mladi nisu demonizirani, već su više predstavljeni kao rizična skupina koja zaslužuje povećanu pozornost aktera u procesu socijalizacije i koja, prema Alexandrescu (2018), na planu upotrebe 
droga nerijetko poprima simbolička obilježja "čistog“ i „vrijednog", ali istodobno metaforički problematičnog. Pritom, kategorija mladih nije diferencirana u sociodemografskim terminima. Marginalizirane skupine poput beskućnika našli smo u člancima koji prenose vijesti o problemu upotrebe NPS-a u drugim zemljama. Ostala sociodemografska obilježja kategorije mladih, od pripadnosti društvenom sloju, (ne)zaposlenosti ili prostornih čimbenika u terminima centra (velikih gradova) i periferije nisu zabilježena. Radoznalost, eksperimentiranje, propitivanje uvriježenih moralnih naputaka na planu poželjnog i nepoželjnog ponašanja i sklonost rizičnom stilu života osnovni su elementi u reprezentaciji mladih kao potencijalne žrtve upotrebe NPS-a.

Sve u svemu, zdravstveni rizici i društvena kontrola na planu upotrebe droga impliciraju medijsko usmjeravanje na normativnu zabrinutost javnosti, što korespondira s Youngovim (1972) opažanjima o nametanju moralnih smjernica univerzumu diskursa poticanjem u smjeru dramatičnog kreiranja društvenih problema. Istraživanje društvene reprezentacije NPS-a u odabranim hrvatskim medijima omogućuje nam da je promotrimo kao važan čimbenik za razumijevanje prirode informacije o tim supstancama. Kao što je upozorio Stanley Cohen, u suvremenim društvima ta informacija je medijski posredovana i, kako se pokazalo u analiziranim člancima, moguće je zaključiti da je plasirana u javni prostor nakon što je prethodno izložena prosudbi predstavlja li vijest ili ne (Cohen, 1972). Stoga već puko izvještavanje o različitim aspektima nekog fenomena (od uhićenja i zapljena do razmjera raširenosti upotrebe) može biti dostatno za generiranje brige i straha. Napokon, inzistiranje na zdravstvenim rizicima i društvenoj kontroli implicitno predstavlja središnji okvir za upućivanje na obrise normativnih kontura društva, na dobro i loše, te dopušteno i nedopušteno. U tom smislu društvena reprezentacija NPS-a u analiziranim člancima prilagođena je zdravorazumskim predodžbama, a kao mehanizam za osmišljavanje proturječnih situacija povezanih s NPS-om kao novim fenomenom obavijenim nepoznanicama, pojednostavljena je i konvencionalizirana u terminima upotrebe droga kao društveno nepoželjne prakse.

\section{OGRANIČENJA}

Metodološka ograničenja odnose se na pouzdanost i na odabir jedinica analize. Dio kvantificiranja proveo je jedan, a dio drugi autor i neovisno o intezivnim zajedničkim provjerama, konzultiranju i usuglašenosti na planu prikupljanja i kodiranja empirijskog materijala, pouzdanost se zasniva tek na stabilnosti, tj. višekratnom čitanju i provjeravanju koherentnosti kodiranja i razvrstavanja jedinica bilježenja u kategorije i njihove preliminarne teme. Premda smo se vodili time da je pouzdanost nalaza u dijelu literature također ostvarena putem stabilnosti (Kassai i sur. 2016), a tamo gdje se i zasnivala na standardnoj proceduri (inter-rater pouzdanost) rezultirala je prihvatljivim koeficijentom uz određenu teoretsko-empirijsku nekonzistentnost (Kordić i sur., 2017), ovaj rad podložan je primjedbama o subjektivnosti procjena. Kada je riječ o određivanju jedinica analize, 105 stavki slikovnog materijala koje smo izdvojili u sklopu istraživanja nije uključeno u analizu jer nismo bili sigurni možemo li kvalitetno provesti vizualnu analizu. U osnovi, naknadno smo ustanovili da smo mogli identificirati neke od elemenata upredmećivanja (događaje, 
objekte, društvene kategorije i sl.), ali smo zaključili da (naknadnim) kvantificiranjem to ne bi u bitnome promijenilo već dobivene rezultate.

Ograničenje mogućnosti procjene dosega i karaktera društvene reprezentacije NPS-a u Hrvatskoj upućuje na to da istraživanjem nisu zahvaćeni ostali akteri koje je nužno uključiti u razmatranje obrazaca društvene reprezentacije NPS-a - od čitatelja i šire javnosti, preko stručnjaka do društvenih kategorija koje se s upotrebom NPS-a najčešće povezuje. To znači da na temelju iznesenih rezultata ne možemo prosuđivati o dosezima i karakteru društvene reprezentacije NPS-a u cjelini i ne možemo utvrditi je li ona pretežno hegemonijska, emancipatorska ili polemička.

Napokon, istraživanjem je zahvaćen tek jedan dio medijski posredovane društvene reprezentacije NPS-a - najčitaniji portali koji imaju i tiskano izdanje. Cjelovit prikaz društvene reprezentacije u online medijima trebao bi zahvatiti ostale portale i medije, kao i razradu njihova neposrednog društvenog konteksta. To bi uključivalo ne samo usporedbu i širu kontekstualizaciju društvene pozicije i uloge svakog od uključena tri portala, nego i širu analizu medija u Hrvatskoj. Budući da su nam u fokusu bili obrasci društvene reprezentacije NPS-a na spomenutim portalima, nismo se bavili razradom pitanja poput njihove vlasničke strukture, političkih i svjetonazorskih orijentacija, tabloidnosti i sl., smatrajući da se radi o temi koja zaslužuju zasebnu studiju.

\author{
Literatura \\ >Alexandrescu, L. (2018). 'Ethnobotanicals' and 'Spice zombies': New psychoactive substances \\ in the mainstream media. Drugs: Education, Prevention and Policy, 25(4), 356-364. https://doi: \\ 10.1080/09687637.2017.1397101 \\ >Bernik, B. (2018). Vodič kroz \$ponzorirane i native članke. eCommerce Hrvatska. Preuzeto 17.6.2018., \\ s https://ecommerce.hr/wp-content/uploads/2018/05/VODIC_EBOOK.pdf \\ $>$ Cohen, S. (1972/80). Folk devils and moral panics. Martin Robertson. \\ $>$ Courtwright, D. (2001). Forces of habit. Drugs and the making of the modern world. Harvard \\ University Press. \\ $>$ Deflem, M. (2015). Deviance and social control. U E. Goode (Ur.), The Handbook of deviance (str. \\ 30-44). Wiley-Blackwell. https://doi: 10.1002/9781118701386 \\ $>$ Dubreta, N. (2005). Društvo i odnos prema drogama. Sociokulturni kontekst upotrebe kanabisa. HSN. \\ $>$ EMCDDA. (2015). New psychoactive substances in Europe. An update from the EU Early Warning \\ System. Publications Office of the European Union. https://doi: 10.2810/372415 \\ $>$ EMCDDA. (2019). Operating guidelines for the European Union Early Warning System on new \\ psychoactive substances. Publications Office of the European Union. https://doi: 10.2810/027404 \\ $>$ Favretto, D., Pascali, P. J., i Tagliaro, F. (2013). New challenges and innovation in forensic toxicology. \\ Focus on the new psychoactive substances. Journal of Chromatography A. 1287, 84-95. https://doi: \\ 10.1016/j.chroma.2012.12.049 \\ $>$ Forsyth, J. M. A. (2001). Distorted? A quantitative exploration of drug fatality reports in \\ the popular press. International Journal of Drug Policy, (12)5-6, 435-453. https://doi: 10.1016/ \\ S0955-3959(01)00092-5 \\ $>$ Glavak Tkalić, R. (2018). Use of new psychoactive substances among the general population in \\ Croatia: Patterns of use and sociodemographic characteristics of users. Alcoholism and Psychiatry \\ Research, (54)1, 5-20. https://doi: 10.20471/may.2018.54.01.01
}


$>$ Goode, E. (2008). Moral panics and disproportionality: The case of LSD use in the sixties. Deviant Behavior, (29)6, 533-543. https://doi: 10.1080/01639620701839377

$>$ Goode, E., i Ben-Yehuda, N. (1994). Moral panics: The social construction of deviance. Blackwell

Publishers.

$>$ Höijer, B. (2011). Social representations theory. A new theory for media research. Nordicom Review, (32)2, 3-16. https://doi: 10.1515/nor-2017-0109

>Jamieson, W. R. (2001). The essence of commodification: Caffeine dependencies in the early modern world. Journal of Social History, (35)2, 269-294.

>Joffe, H. (2003). Risk: From perception to social representation. British Journal of Social Psychology, (42)1, 55-73. https://doi: 10.1348/014466603763276126

>Kassai, S., Rácz, J., Nagy, A., Bíbók, T., Galambvári, E., Kilián, C., i Gyarmathy, V. A. (2016). "Someone else's problem": New psychoactive substances in the online Hungarian media, Journal of Psychoactive Drugs, (49)1, 47-51. https://doi:10.1080/02791072.2016.1267419

>Kordić, Lj., Hromadžić, H., i Karlić, J. (2017). Medijske reprezentacije ovisnika i ovisnosti o psihoaktivnim tvarima u dnevnom tisku u Hrvatskoj. Medijske studije, (8)16, 23-40. https://doi: $10.20901 / \mathrm{ms} .8 .16 .3$

>Krippendorff, K. (2004). Content analysis: An introduction to its methodology. Sage Publications, Inc. $>$ Liu, L. (2004). Sensitising concept, themata and shareness: A dialogical perspective of social representations. Journal for the Theory of Social Behaviour, (34)3, 249-264.

>Lugarić, K. (2018). Društvena reprezentacija novih psihoaktivnih supstanci: Analiza sadržaja općeinformativnih web portala u RH. Diplomski rad. Sveučilište u Zagrebu: Hrvatski studiji.

$>$ Marková, I. (2003). Dialogicality and social representations. The dynamics of mind. Cambridge University Press.

$>$ Markova, I. (2015). On thematic concepts and methodological (epistemological) themata. Papers on Social Representations, (24)2, 4.1-4.31.

$>$ McRobbie, A., i Thornton, L. S. (1995). Rethinking 'moral panic' for multi-mediated social worlds. The British Journal of Sociology, (46)4, 559-574. https://doi: 10.2307/591571

$>$ Miller, B. L., Stogner, J. M., Agnich, L. E., Sanders, A., Bacot, J., i Felix, S. (2015). Marketing a panic: Media coverage of novel psychoactive drugs (NPDs) and its relationship with legal changes.

American Journal of Criminal Justice, (40)3, 523-541. https://doi: 10.1007/s12103-014-9270-6

$>$ Moloney, G., Gamble, M., Hayman, J., \& Smith, G. (2015). Without anchor: Themata and blood donation. Papers on Social Representations, (24)2, 2.1-2.21

$>$ Moscovici, S. (1984). The phenomenon of social representations. U M. R. Farr i S. Moscovici (Ur.) Social representations (str. 3-70). Cambridge University Press.

$>$ Moscovici, S. (Ur.) (2000). Social representations. Cambridge University Press.

>Pelbát, G., Gyarmathy, V. A., Bacsó, A., Bartos, E., Bihari, A., i Rácz, J. (2016). Portrayal of new psychoactive substances in the Hungarian online media. International Journal of Mental Health and Addiction, (15)1, 110-117. https://doi: 10.1007/s11469-015-9629-z

>Pirona, A., Bo, A., Hedrich, D., Ferri, M., Gelder, N., Giraudon, I., Montanari, L., Simon, R., i Mounteney, J. (2016). New psychoactive substances: Current health-related practices and challenges in responding to use and harms in Europe. International Journal of Drug Policy, 40, 84-92. https://doi: 10.1016/j.drugpo.2016.10.004

$>$ Reuter, P. i Pardo, B. (2016). New psychoactive substances: Are there any good options for regulating new psychoactive substances? International Journal of Drug Policy, 40, 117-122. https:// doi: 10.1016/j.drugpo.2016.10.020

>Seddon, T. (2014). Drug policy and global regulatory capitalism: The case of new psychoactive substances (NPS). International Journal of Drug Policy, (25)5, 1019-1024. https://doi: 10.1016/j. drugpo.2014.03.009

>Skoko, B. i Vrdoljak, N. (2018). Stvarni dosezi news portala - međuodnos čitanosti, vjerodostojnosti i utjecaja. Hum, (13)19, 79-97. 
IZVORNI ZNANSTVENI RAD / DOI: 10.20901/ms.12.23.6 / PRIMLJENO: 23.7.2020.

$>$ Smith, W. N. \& Joffe, H. (2009). Climate change in the British press: The role of the visual. Journal of Risk Research, (12)5, 647-663. https://doi: 10.1080/13669870802586512

$>$ Swalve, N. i DeFoster, R. (2016). Framing the danger of designer drugs: Mass media, bath salts, and the "Miami zombie attack". Contemporary Drug Problems, (43)2, 103-121. https://doi: $10.1177 / 0091450916642515$

$>$ Wallerstein, I. (1986). Suvremeni svjetski sistem. Zagreb: CEKADE.

$>$ Young, J. (1972). Drugtakers: The social meaning of drug use. London: Paladin. 


\section{SOCIAL REPRESENTATION OF NEW PSYCHOACTIVE SUBSTANCES ON CROATIAN NEWS WEBSITES}

\section{Nikša Dubreta :: Karlo Lugarić}

ABSTRACT This paper deals with media representation of new psychoactive substances in the light of the theory of social representation. Since new psychoactive substances represent a relatively unknown phenomenon in the Croatian social context, the article explains the analytical usefulness of communicative mechanisms of social representation that can be used in media research. The research was conducted by means of content analysis of articles addressing the issue of new psychoactive substances, posted on the selected news websites in a period of seven years. The results suggest that naming, emotional anchoring and emotional objectification are key communicative mechanisms in generating social representation of new psychoactive substances in the analysed media. The analysis of implied basic values, embodied in the published articles suggests that the emphasis on health risks and weaknesses in the activities of social control of new psychoactive substances are conventionalized through the theme of society without drugs.

KEY WORDS

NEW PSYCHOACTIVE SUBSTANCES, SOCIAL REPRESENTATION, ANCHORING, OBJECTIFICATION, DRUG USE

Authors' note

Nikša Dubreta :: University of Zagreb, Faculty of Mechanical Engeneering and Naval Architecture :: niksa.dubreta@fsb.hr

Karlo Lugarić :: karlo.lugaric@yahoo.com 